\title{
Role of HIV-I subtype C envelope V3 to V5 regions in viral entry, coreceptor utilization and replication efficiency in primary T-lymphocytes and monocyte-derived macrophages
}

\author{
Vasudha Sundaravaradan ${ }^{\dagger 1}$, Suman R Das ${ }^{\dagger 2,4}$, Rajesh Ramakrishnan ${ }^{1,5}$, \\ Shobha Sehgal ${ }^{3}$, Sarla Gopalan ${ }^{3}$, Nafees Ahmad ${ }^{* 1}$ and Shahid Jameel*2
}

\begin{abstract}
Address: ${ }^{1}$ Department of Immunobiology, College of Medicine, University of Arizona, Tucson, AZ 85724, USA, ${ }^{2}$ Virology Group, International Center for Genetic Engineering and Biotechnology, New Delhi, India, ${ }^{3}$ Departments of Pathology and Obstetrics and Gynecology, Post Graduate Institute of Medical Education and Research, Chandigarh, India, ${ }^{4}$ NIAID, National Institutes of Health, Bethesda, MD 20892, USA and

${ }^{5}$ Department of Molecular Virology \& Microbiology, Baylor College of Medicine, Houston, TX 77030, USA

Email: Vasudha Sundaravaradan - vsvaradan@yahoo.com; Suman R Das - dassr@niaid.nih.gov; Rajesh Ramakrishnan - ramakris@bcm.tmc.edu; Shobha Sehgal - sehgal@hotmail.com; Sarla Gopalan - Gopalan@hotmail.com; Nafees Ahmad* - nafees@u.arizona.edu;

Shahid Jameel* - jameelshahid@gmail.com

* Corresponding authors †Equal contributors
\end{abstract}

Published: 24 November 2007

Virology Journal 2007, 4:126 doi:10.1186/1743-422X-4-126

This article is available from: http://www.virologyj.com/content/4/I/I26

(C) 2007 Sundaravaradan et al; licensee BioMed Central Ltd.

This is an Open Access article distributed under the terms of the Creative Commons Attribution License (http://creativecommons.org/licenses/by/2.0), which permits unrestricted use, distribution, and reproduction in any medium, provided the original work is properly cited.
Received: 9 October 2007

Accepted: 24 November 2007

\begin{abstract}
Background: Several subtypes of HIV-I circulate in infected people worldwide, including subtype $B$ in the United States and subtype $C$ in Africa and India. To understand the biological properties of HIV-I subtype C, including cellular tropism, virus entry, replication efficiency and cytopathic effects, we reciprocally inserted our previously characterized envelope V3-V5 regions derived from 9 subtype $C$ infected patients from India into a subtype $B$ molecular clone, pNL4-3. Equal amounts of the chimeric viruses were used to infect T-lymphocyte cell lines (A3.0I and MT-2), coreceptor cell lines (U373-MAGI-CCR5/CXCR4), primary blood T-lymphocytes (PBL) and monocyte-derived macrophages (MDM).
\end{abstract}

Results: We found that subtype $\mathrm{C}$ envelope $\mathrm{V} 3-\mathrm{V} 5$ region chimeras failed to replicate in Tlymphocyte cell lines but replicated in PBL and MDM. In addition, these chimeras were able to infect U373MAGI-CD4+-CCR5 $5^{+}$but not U373MAGI-CD4+-CXCR4+ cell line, suggesting CCR5 coreceptor utilization and R5 phenotypes. These subtype $C$ chimeras were unable to induce syncytia in MT-2 cells, indicative of non-syncytium inducing (NSI) phenotypes. More importantly, the subtype $C$ envelope chimeras replicated at higher levels in PBL and MDM compared with subtype $B$ chimeras and isolates. Furthermore, the higher levels subtype $C$ chimeras replication in $\mathrm{PBL}$ and MDM correlated with increased virus entry in U373MAGI-CD4+-CCR5 ${ }^{+}$.

Conclusion: Taken together, these results suggest that the envelope $\mathrm{V} 3$ to $\mathrm{V} 5$ regions of subtype $C$ contributed to higher levels of HIV-I replication compared with subtype B chimeras, which may contribute to higher viral loads and faster disease progression in subtype $C$ infected individuals than other subtypes as well as rapid HIV-I subtype C spread in India. 


\section{Introduction}

The steepest increase in new cases of human immunodeficiency virus type 1 (HIV-1) infection has taken place in South America [1] and South/Southeast Asia [2], of which India is experiencing a rapid and extensive spread of infection. National surveys in India have shown that the spread in India is primarily heterosexual in the metropolitan and coastal cities, and via intravenous drug use in the Northeast bordering Myanmar [3,4]. The HIV-1 sequences analyzed from different cohorts from several regions in India suggests that HIV-1 subtype $\mathrm{C}$ is the predominant subtype found in India [3-8]. It has also been shown in several African and South American studies that subtype C rapidly predominates over all the other HIV-1 subtypes after being introduced in those populations $[1,9]$, suggesting that subtype $\mathrm{C}$ may soon become the prevalent subtype worldwide. However, the biological properties of HIV-1 subtype $\mathrm{C}$ viruses that may influence its rapid spread are not known.

HIV-1 envelope gp120 interacts with CD4 receptor and CXCR4 or CCR5 coreceptor [10-13] on T lymphocytes, monocytes/macrophages and other cell types [11,14,15] to enter target cells. Analysis of env gp120 sequences from a large number of HIV-1 isolates shows that gp120 is made up of five variable regions (V1 to V5) that are interspersed with conserved regions [16]. The potential pathogenic region of $\mathrm{HIV}-1$ presumably lies within these variable regions, especially in the $\mathrm{V} 3$ region comprising of 35 amino acids arranged in a disulphide loop involving two cysteines [10]. The hypervariable region 3, the V3 region, is functionally important in virus infectivity [1719], virus neutralization [13,20-22], replication efficiency and host cell tropism $[10,23]$, whereas the V1-V2 regions influence replication efficiency in macrophages by affecting virus spread [24,25]. In addition, the variable loops V4 and V5 of gp120 are less flexible regions of the proteins and may play roles in CD4 binding and neutralizing antibody responses $[26,27]$. The mechanisms by which the V3 domain and other regions of the env glycoprotein control cell tropism were described by identifying two distinct coreceptors, fusin (CXR4) and CCR5, for the entry of T-lymphotropic and macrophage-tropic $\mathrm{HIV}-1$, respectively $[11,15]$. The region responsible for determining coreceptor utilization was examined by Choe et al., [12] and showed that the $\mathrm{V} 3$ region was responsible for interacting with this co-receptor. Several studies have shown that a reciprocal transfer of an HIV-1 R5 clones' V3 region into an X4 molecular clone changed its tropism to allow infection and replication in macrophages [10,19,23,28-30]. However, most of the data on viral infectivity, coreceptor utilization, replication efficiency and cytopathic effects have been obtained from HIV-1 subtype B, and very limited information is available on subtype $\mathrm{C}$ viruses, especially those from India.
In this study, we have characterized the biological properties of HIV-1 subtype C envelope V3 to V5 regions by constructing chimeric recombinant viruses containing subtype $\mathrm{C}$ envelope V3-V5 regions from nine infected patients from India [5] into subtype B infectious molecular clone, pNL4-3. We show that the envelope V3-V5 regions of HIV-1 subtype $\mathrm{C}$ changed the tropism of HIV-1 NL4-3 from X4 to R5 and contributed to the increased virus entry and replication efficiency in primary blood $\mathrm{T}$ lymphocytes (PBL) and monocyte-derived macrophages (MDM) compared with subtype B viruses. This higher replication efficiency of subtype $\mathrm{C}$ compared with subtype $\mathrm{B}$ may contribute to a higher viral load and faster disease progression in patients infected with HIV-1 subtype C viruses in the Indian population.

\section{Results \\ Characterization and comparison of subtype $C$ envelope V3-V5 chimeras' sequences with known isolates}

We confirmed the reciprocal insertion of the sixteen envelope V3-V5 region sequences (Fig. 1) from nine subtype $\mathrm{C}$ infected patients' isolates from India (Table 1) that were sequenced before [5] into pNL4-3 by nucleotide sequencing. Two clones were selected from each patient for reciprocal insertion. The patients harbored various stages of HIV disease (I to IVE) based on the 1987 CDC classification. We also compared the subtype $\mathrm{C}$ env V3 to V5 regions chimeras with $\mathrm{HIV}-1_{\mathrm{NL} 4-3}, \mathrm{HIV}-1_{\mathrm{BaL}}$ and a known env $\mathrm{V} 3-\mathrm{V} 5$ region sequence of subtype $\mathrm{C}$ (Fig. 1). All the subtype $\mathrm{C} e n v \mathrm{~V} 3-\mathrm{V} 5$ clones showed a greater similarity to the R5 virus $\mathrm{HIV}-1_{\mathrm{BaL}}$ than $\mathrm{HIV}-1_{\mathrm{NL} 4-3}$. The amino acids critical for the $\mathrm{R} 5$ phenotype, including the $\mathrm{Y}$ at position 283 and $\mathrm{E}$ or $\mathrm{D}$ at position 287 were present in all subtype $\mathrm{C}$ clones. The amino acid $\mathrm{H}$ at position 275 seen in HIV$1_{\mathrm{Ba}-\mathrm{L}}$ which is also important for determining $\mathrm{R} 5$ tropism was present only in the clones from patient 17 (clones 171 and 173). The amino acid sequences between positions 310-315 and 350-373 were significantly different from HIV $-1_{\text {NL4-3 }}$ clone but were very similar to the previously known sequence of subtype $\mathrm{C}$ envelope region. It is interesting to note that a critical glycosylation site, which includes the first cysteine of the V3 loop, was mutated in all the clones except those obtained from patient 17 and 5 (clones 171, 173, 512, 514). The sequence analysis of all the clones indicate that these clones are different from HIV- $1_{\text {NL4-3 }}$ envelope sequences but very similar to envelope sequences from known subtype $\mathrm{C}$ clones and to $\mathrm{R} 5$ tropic viruses such as $\mathrm{HIV}-1_{\mathrm{BaL}}$.

\section{Computational prediction of coreceptor usage using V3 amino acid sequence of subtype $\boldsymbol{C}$ chimeras}

We also used the Position Specific Scoring Matrix (PSSM) bioinformatics tool (X4/R5) to predict coreceptor usage by the Subtype C patient env V3-V5 region sequences [31] and calculated scores for each clone are shown in Table 2. 


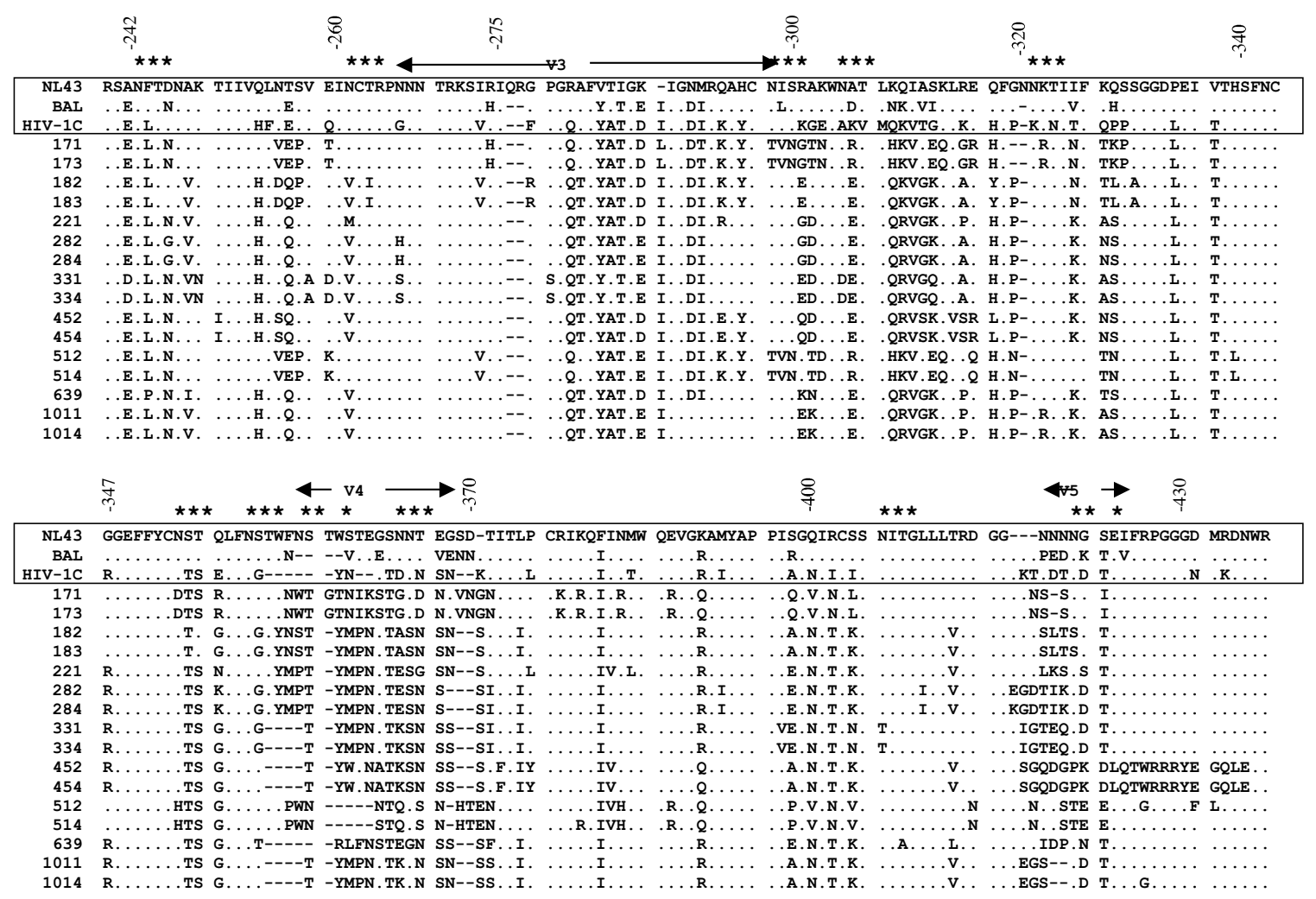

Figure I

Comparison of envelope (V3 to V5 regions) from subtype $C$ chimeras with subtype $B(X 4$ and $R 5$ ) and $C$ envelope sequences. The sequences of subtype $C$ env chimeras used in this study were analyzed by performing multiple sequence alignment with parental clone HIV-I $\mathrm{NL4-3}_{3}$ as a reference and HIV-I $\mathrm{I}_{\mathrm{BaL}}$ and known HIV-I subtype $\mathrm{C}$ envelope regions for comparison. Subtype $\mathrm{C}$ chimeras are designated by numbers. Dots indicate a match with the reference sequence whereas substitutions are indicated by the single letter code for the changed amino acid. Gaps are shown as dashes. Structural elements of the envelope are indicated by spanning arrowheads and glycosylation sites are indicated by asterisk. Amino acid positions are indicated to denote the amino acid numbers of the complete envelope gp I 20.

Table I: Patient demographics, possible source and risk factor of transmission and CDC disease classification.

\begin{tabular}{|c|c|c|c|c|c|}
\hline Patient Code & Chimeras Number & Age/Sex & Possible source & Risk factor & CDC classification \\
\hline AP.I7 & 171,173 & $27 / M$ & Africa/Germany & $\begin{array}{l}\text { Promiscuous } \\
\text { heterosexual }\end{array}$ & IV-C, D \\
\hline AP. 18 & 182,183 & I4/M & Punjab (India) & Blood transfusion & IV-E \\
\hline AP. 2 & $221 \mathrm{~A}$ & $20 / M$ & Dubai/Punjab & $\begin{array}{l}\text { Promiscuous } \\
\text { heterosexual }\end{array}$ & II \\
\hline AP.28 & 282,284 & $28 / M$ & Kolkata (India) & Truck driver & IV \\
\hline AP.33 & 331,334 & $26 / M$ & Punjab & Hemophiliac & 1 \\
\hline AP. 4 & 452,454 & $25 / M$ & Mumbai (India) & $\begin{array}{l}\text { Promiscuous } \\
\text { heterosexual }\end{array}$ & IV-C \\
\hline AP. 5 & $512,5 \mid 4$ & $23 / F$ & Africa/Germany & Spouse with AIDS & II \\
\hline AP.6 & 639 & $27 / M$ & Punjab & $\begin{array}{l}\text { Promiscuous } \\
\text { heterosexual }\end{array}$ & II \\
\hline AP. 10 & 1011,1014 & $25 / M$ & Mumbai & Blood transfusion & IV-C \\
\hline
\end{tabular}

CDC-Center for Disease Control and Prevention 
Table 2: Prediction of coreceptor usage by Position Specific Scoring Matrix (PSSM) bioinformatics tool that predicts coreceptor usage.

\begin{tabular}{|c|c|c|c|c|c|c|c|c|c|}
\hline $\begin{array}{l}\text { Patient/ } \\
\text { Clone }\end{array}$ & Software & Score & Pred & X4 pct & R5 pct & Geno & Pos chg & Net Chg & Percent \\
\hline \multirow{2}{*}{$\begin{array}{c}\text { AP.I7/I7I, } \\
173\end{array}$} & X4/R5 & -3.58 & 0 & 0.47 & 0.98 & SE & 6 & 4 & 0.83 \\
\hline & Sinsi & -7.05 & 0 & 0.04 & 0.90 & SE & 6 & 4 & 0.83 \\
\hline \multirow{2}{*}{$\begin{array}{c}\text { AP. } 18 / 182, \\
183\end{array}$} & X4/R5 & -6.48 & 0 & 0.27 & 0.95 & SD & 6 & 4 & 0.70 \\
\hline & Sinsi & -10.73 & 0 & 0.04 & 0.58 & SD & 6 & 4 & 0.70 \\
\hline \multirow[t]{2}{*}{ AP. $2 / 221 \mathrm{~A}$} & X4/R5 & -7.83 & 0 & 0.22 & 0.9 & SD & 7 & 5 & 0.57 \\
\hline & Sinsi & -9.5 & 0 & 0.04 & 0.73 & SD & 7 & 5 & 0.57 \\
\hline \multirow{2}{*}{$\begin{array}{c}\text { AP.28/282, } \\
284\end{array}$} & X4/R5 & -8.89 & 0 & 0.22 & 0.88 & SE & 7 & 5 & 0.44 \\
\hline & Sinsi & -12.12 & 0 & 0.01 & 0.2 & SE & 7 & 5 & 0.44 \\
\hline \multirow{2}{*}{$\begin{array}{c}\text { AP.33/33I } \\
334\end{array}$} & $\times 4 / R 5$ & -7.36 & 0 & 0.24 & 0.92 & SE & 6 & 4 & 0.62 \\
\hline & Sinsi & -10.61 & 0 & 0.04 & 0.51 & SE & 6 & 4 & 0.62 \\
\hline \multirow{2}{*}{$\begin{array}{c}\text { AP. } 4 / 452 \\
454\end{array}$} & X4/R5 & -6.50 & 0 & 0.27 & 0.95 & SD & 5 & 2 & 0.67 \\
\hline & Sinsi & -11.53 & 0 & 0.01 & 0.32 & SD & 5 & 2 & 0.67 \\
\hline \multirow{2}{*}{$\begin{array}{c}\mathrm{AP} .5 / 512 \\
514\end{array}$} & X4/R5 & -9.74 & 0 & 0.22 & 0.82 & SE & 5 & 3 & 0.33 \\
\hline & Sinsi & -10.69 & 0 & 0.01 & 0.50 & SE & 5 & 3 & 0.33 \\
\hline \multirow[t]{2}{*}{ AP.6/639 } & X4/R5 & -9.06 & 0 & 0.22 & 0.86 & SD & 6 & 4 & 0.48 \\
\hline & Sinsi & -12.26 & 0 & 0.01 & 0.17 & SD & 6 & 4 & 0.48 \\
\hline \multirow{2}{*}{$\begin{array}{l}\text { AP.10/1011, } \\
1014\end{array}$} & X4/R5 & -9.36 & 0 & 0.22 & 0.83 & SE & 6 & 4 & 0.31 \\
\hline & Sinsi & -11.16 & 0 & 0.01 & 0.04 & SE & 6 & 4 & 0.31 \\
\hline
\end{tabular}

A score of -6.96 was used as a cut off for R5 strains and a score of -2.88 was used as a cutoff for X4 strains. Most of these scores were higher than -6.96 especially AP.17 sequence which showed a score of -3.58 clearly below the cut-off score for X4 strains. Thus, all the clones were clearly predicted to be $\mathrm{R} 5$ tropic. We also used the PSSM (sinsi) matrix to analyze these sequences and these scores were in the range of -7.5 to -11.53 . This predicts high R5 tropism and a NSI phenotype for all the Indian isolates examined. Higher numbers of positively charged amino acids $(\mathrm{R} / \mathrm{K} / \mathrm{H})$ have been correlated with the likelihood of CXCR4 use. In all of the Indian sequences in this study, lower numbers of positive charges, in the range of 5 to 7 , were found (Table 2). Thus, in an in-silico prediction model, all of the V3-V5 sequences of HIV-1 Indian isolates were predicted to show R5-tropism.

\section{Replication of subtype C chimeric viruses in T- Lymphocyte cell lines}

We first sought to determine whether the subtype $\mathrm{C}$ env chimeras retained the lymphotropic properties of the parental clone HIV-1 $1_{\mathrm{NL} 4-3}$ by infecting the $\mathrm{T}$ cell line A3.01 with the subtype $\mathrm{C}$ chimeric viruses and parental virus, $\mathrm{HIV}-1_{\mathrm{NL} 4-3}$. The T-cell line A3.01 expresses CD4 and CXCR4 but no CCR5. Our results showed that the parental X4 tropic HIV-1 $1_{\mathrm{NL} 4-3}$ productively infected and replicated in A3.01 over a 27-day infection period.
However, the subtype $\mathrm{C}$ chimeras did not replicate in A3.01 cell line (Fig. 2), suggesting that these chimeras were no longer T-cell line tropic, unlike the parental clone. These results further demonstrated that replacement of the V3-V5 regions of envelope of HIV-1 $1_{\text {NL4-3 }}$ with subtype $\mathrm{C}$ envelope from infected patients was responsible for the lack of capacity to use CXCR4 as a coreceptor for these chimeric viruses. These data also suggest that the integrated proviruses that were present in these subtype $\mathrm{C}$ infected patient samples were not X4 tropic.

\section{Coreceptor utilization of chimeric subtype $\boldsymbol{C}$ viruses}

We then determined the coreceptor utilization of the subtype $\mathrm{C} e n v$ chimeras (clone designation in Fig. 1 and Table 1) using U373-MAGI indicator cell lines. These cell lines express the CD4 receptor in conjunction with either CCR5 or CXCR4 as a coreceptor and can be infected with either macrophage tropic (R5) or lymphotropic (X4) viruses, respectively. These cells contain an inducible $\beta$-galactosidase reporter driven by HIV-1 LTR that can be used as an indicator for entry. The known SI isolate HIV-1 $1_{\mathrm{NL4}-3}$, NSI isolate $\mathrm{HIV}-1_{\mathrm{BaL}^{\prime}}$ and primary isolates were used as controls. As shown in Table 3, all the subtype C env chimeras were able to infect the U373-MAGI-CCR5 cell line but were unable to infect the U373-MAGI-CXCR4 cell line. This data also correlates well with the insilico prediction 


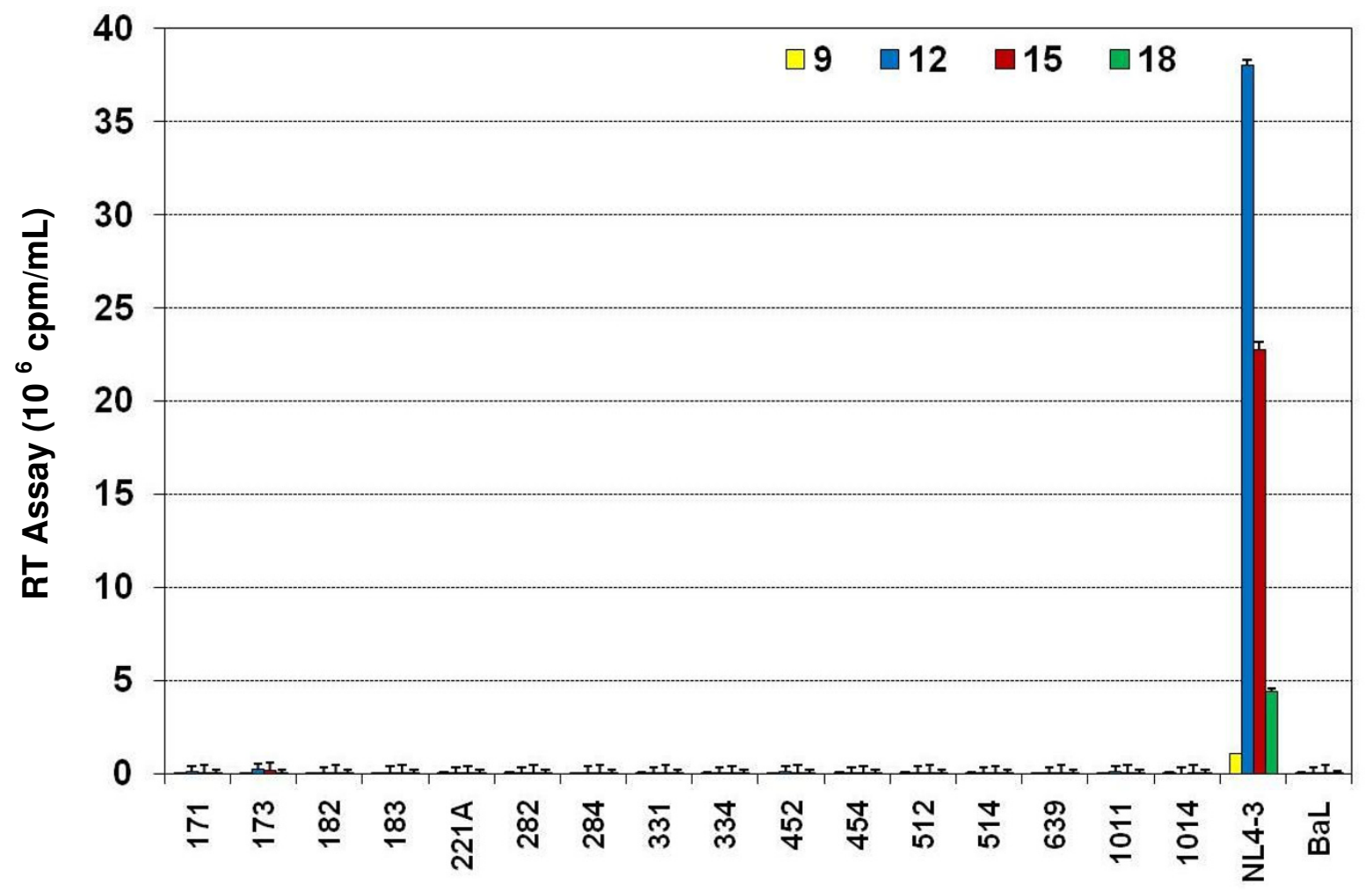

Viral Isolates

Figure 2

Replication of HIV-I subtype C env V3-V5 region chimeras in T-lymphocyte (A3.0I) cell line. A3.0I cells (I $\times 10^{6}$ cells/well) were infected with equal amounts (RT counts) subtype $C$ env chimeras (I7I to I0I4), parental HIV- $I_{N L 4-3}$ and HIV-I ${ }_{B a L}$. Virus production was measured by reverse transcriptase (RT) assay in culture media harvested every 3 days and the cells fed with appropriate media. The results are presented as $\mathrm{cpm} / \mathrm{ml} \pm \mathrm{SD}$ of five separate triplicate experiments. The subtype $C$ chimeras were unable to replicate in $\mathrm{A} 3.0 \mathrm{I}$ cell line.

models and confirms the coreceptor usage of these viruses. This data suggests that the cloning of these chimeras yielded functional envelope regions that can bind CD4/CCR5 and allow virus entry and production of early viral genes. As seen by the counts for infectivity of the MAGI-CCR5 line, the chimeras showed considerable differences in infectivity. Some chimeras $(171,173)$ demonstrated remarkably high levels of infectivity when compared to other chimeras and primary isolate controls indicating an increased rate of entry for these chimeras. The levels of entry using increasing virus counts (5000 and 10,000 RT counts) during infection showed increased level of entry for the same chimeras. This shows that the envelope region of subtype C HIV-1 obtained from the patient samples shows an R5 phenotype for the virus infecting the patient. These results also suggest that all the chimeric viruses obtained could have had different rates of entry when infecting target cells. This can be attributed to the differences in the $\mathrm{V} 3$ region of the subtype $\mathrm{C}$ chimeric DNA, reflecting the differences found in patient samples. This also adds to previous work done by others $[4,32,33]$ showing that the coreceptor utilization of subtype C HIV-1 could be predominantly R5 even late in infection.

\section{Syncytium inducing capacity of subtype $C$ chimeras}

We examined the syncytium-inducing ability of the subtype $\mathrm{C}$ env chimeras by infecting MT-2 cell lines with the chimeric viruses. Viruses that produce a greater than four syncytia per field were denoted as syncytium inducing (SI) phenotype and the viruses that did not induce any syncytia were called as non-syncytium inducing (NSI) phenotype. As shown in the Table 3, all of the subtype C V3-V5 region chimeras failed to produce any syncytia in MT-2 cells and therefore are of the NSI phenotype (similar to known R5 isolates $\mathrm{HIV}-1_{\mathrm{BaL}}$ ). The control parental virus HIV-1 $1_{\mathrm{NL4}-3}$ that has a known SI phenotype produced significant levels of syncytia (at least 10 per field of view). As expected, the 
Table 3: Coreceptor usage by HIV-I subtype $C$ chimeras in U373-MAGI-CCR5 and U373-MAGI-CXCR4 cell lines.

\begin{tabular}{|c|c|c|c|c|c|}
\hline \multirow[b]{2}{*}{ Infection counts $\rightarrow$} & \multicolumn{2}{|c|}{ MAGI-CCR5 } & \multicolumn{2}{|c|}{ MAGI-CXCR4 } & \multirow[b]{2}{*}{$\begin{array}{c}\text { Phenotype from } \\
\text { MT-2 }\end{array}$} \\
\hline & 5000 & 10000 & 5000 & 10000 & \\
\hline CHIMERA_ & \multicolumn{2}{|c|}{ No. of blue cells } & \multicolumn{2}{|c|}{ No. of blue cells } & \\
\hline$|7|$ & 21 & 99 & - & - & NSI \\
\hline 173 & 23 & 92 & - & - & NSI \\
\hline 182 & 9 & 18 & - & - & NSI \\
\hline 183 & 7 & 12 & - & - & NSI \\
\hline $221 \mathrm{~A}$ & 0 & 2 & - & - & NSI \\
\hline 282 & 9 & 30 & - & - & NSI \\
\hline 284 & 2 & 6 & - & - & NSI \\
\hline 331 & 13 & 31 & - & - & NSI \\
\hline 334 & 1 & 2 & - & - & NSI \\
\hline 452 & 23 & 65 & - & - & NSI \\
\hline 512 & 1 & 3 & - & - & NSI \\
\hline 514 & I & 4 & - & - & NSI \\
\hline 639 & 1 & 2 & - & - & NSI \\
\hline 1011 & 11 & 26 & - & - & NSI \\
\hline 1014 & 16 & 33 & - & - & NSI \\
\hline 2099 (B-R5) & 8 & 19 & - & - & NSI \\
\hline 2101 (B-X4/R5) & 5 & 10 & 10 & 21 & $\mathrm{SI}$ \\
\hline $304 I$ (C-R5) & 7 & 34 & - & - & NSI \\
\hline $544 \mathrm{I}(\mathrm{C}-\mathrm{X} 4)$ & - & - & 23 & 38 & $\mathrm{SI}$ \\
\hline
\end{tabular}

$\mathrm{NSI}$ - non-syncytium inducing, SI - syncytium inducing, - indicate no entry due to lack of blue cells.

R5 viruses used as control also did not produce syncytia in culture. These data suggest that the envelope sequences from subtype $\mathrm{C}$ infected patient samples render them less cytopathic as compared to HIV-1 $1_{\mathrm{NL} 4-3}$. We also confirmed virus production in MT-2 cells and the syncytium formation correlated to virus production in our partial env (V3V5) region chimeras (NSI) and R5 isolates as measured by RT assay in the culture medium (not shown).

\section{Replication of subtype C chimeras in primary peripheral blood T-lymphocytes}

Primary T-lymphocytes from peripheral blood express CD4 and both chemokine receptors, CXCR4 and CCR5. Since PBL express both CCR5 and CXCR4, they are capable of supporting the replication of both $\mathrm{R} 5$ and $\mathrm{X} 4$ tropic viruses. All the subtype $\mathrm{C}$ env chimeras, which did not replicate in A3.01, were able to replicate in PBL showing that there was no inherent defect in their replication as a results of the reciprocal insertion of the V3-V5 region from patient samples (Fig. 3). Although we have demonstrated the entry of these chimeric viruses using the MAGI cell experiments, the replication kinetics shown in Figure 3 confirm the capacity of these viruses to enter and replicate well in culture.

The replication kinetics of subtype $C$ chimeras in PBL showed that these chimeras replicated at a higher efficiency as compared to subtype B chimeras (M5g, M7f, and M1C [34]) and subtype B isolates. Close observation showed that chimeras 171 and 173 replicated and peaked much earlier in infection as compared to the other chimeras. The V3-V5 region of these chimeras came from a patient who demonstrated advanced disease (Table 1) [5]. Although some chimeras (284 and 331) peaked relatively late in infection, they peaked at higher levels than the subtype $\mathrm{B}$ chimeras. All the subtype $\mathrm{C}$ chimeras also replicated at levels higher than the subtype B primary isolates. The replication data of the subtype $\mathrm{C}$ chimeras (Fig. 3) correlated well with the rate of entry seen in the MAGI cell line experiments (Table 3). The chimeras that scored higher numbers in MAGI cell experiments (Table 3) peaked earlier in viral infection experiments (Fig. 3). Comparative rates of entry of chimeras correspond with the peak of viral replication, where 171 and 173 with highest level of entry in MAGI cells showed very early and high peaks and 284 and 331 chimeras with much lower level of entry showed lower and/or more delayed peaks. It is interesting to note that chimeras $171,173,512$ and 514 , which retained the first proximal glycosylation site of the V3 region (Fig 1), peaked very early (Day 6-9) during replication (Fig 3). Comparison of the primary isolates of subtype $\mathrm{B}$ and subtype $\mathrm{C}$ also showed that the subtype $\mathrm{C}$ primary isolates replicated better than the subtype $\mathrm{B}$ primary isolates. These data suggest that the envelope V3 to V5 regions of 


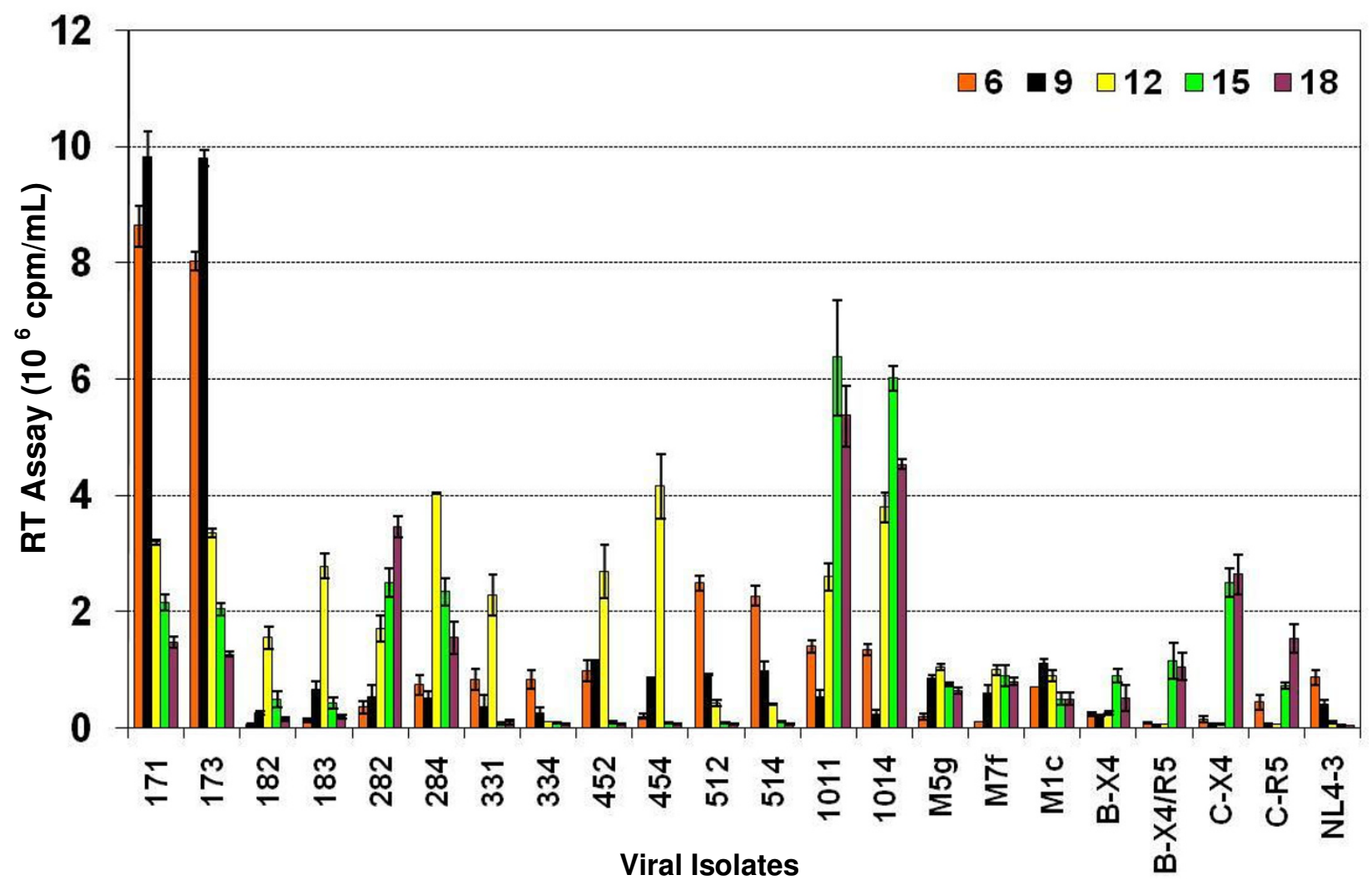

Figure 3

Replication of HIV-I subtype C env V3-V5 region chimeras in primary peripheral blood T-lymphocytes $(\mathrm{PBL})$. PBL $\left(\mathrm{I} \times 10^{6}\right.$ cells/well) were stimulated with PHA and infected with equal amounts (reverse transcriptase counts) of subtype C env V3-V5 region chimeras, subtype $B$ env $V 3$ region chimeras, primary subtype $B$ isolates, primary subtype $C$ isolates and parental HIV$\mathrm{I}_{\mathrm{NL4-3}}$. Cells were fed every 3 days with appropriate medium and virus production was measured in the culture supernatant by RT assay. The data are presented as $\mathrm{cpm} / \mathrm{ml} \pm \mathrm{SD}$ on triplicate experiments and are based on PBL from five different donors.

the subtype $\mathrm{C}$ influenced the rate of replication of HIV-1 in primary T-lymphocytes and determined the cellular tropism. Furthermore, there was a direct relationship between higher viral replication (Fig. 3) and advanced disease status of the patients (Table 1).

\section{Replication of subtype C chimeras in primary monocyte- derived macrophages}

While primary monocyte derived macrophages (MDM) express CD4 and CCR5 and a low level of CXCR4, they support productive infection of R5 but not X4 viruses. As the subtype $\mathrm{C}$ chimeras showed a R5 phenotype (Table 3 ), replication kinetics of these chimeras were evaluated in MDM. Figure 4 shows the replication kinetics of subtype $\mathrm{C}$ chimeras in comparison with primary subtype $\mathrm{B}$ and $\mathrm{C}$ controls. The data clearly demonstrated that subtype $\mathrm{C}$ chimeras replicated better than subtype $B$ viruses. The rate of replication of the subtype $\mathrm{C}$ chimeras in MDM also correlated with the rate of entry of the chimeras in MAGI-CCR5 cell line, further supporting the hypothesis that the increase in the replication of these chimeras is due to increase in the rate of entry. Both subtype B (2099) and subtype C (3041) primary R5 isolates replicated in MDM and subtype B dual tropic (X4/R5) virus (2101) also showed adequate replication in MDM. In addition, comparison of subtype $\mathrm{B}$ and subtype $\mathrm{C}$ primary isolates also showed that the subtype $\mathrm{C}$ primary isolates replicated better than subtype $\mathrm{B}$ primary isolates. These data suggest that the V3 to V5 regions of subtype $\mathrm{C}$ influenced increased replication of HIV-1 in MDM.

\section{Discussion}

We have provided evidence regarding the role of the HIV1 envelope V3-V5 regions from subtype $\mathrm{C}$ infected patients from India in virus entry, coreceptor utilization and replication efficiency in primary T-lymphocytes and macrophages in comparison with those of subtype $B$ viruses. Our data suggest that the reciprocal insertion of 
HIV-1 subtype C infected patients' envelope V3 to V5 regions [5] into subtype B molecular clone, contributed to utilization of CCR5 coreceptor (Table 3) as well as higher levels of HIV-1 entry and replication efficiencies in primary T-lymphocytes (Fig. 3) and MDM (Fig. 4). The higher viral replication efficiencies of R5 phenotype of the chimeras correlated with advanced disease status of the patients (Table 1). Taken together, the increased replication capabilities of HIV-1 subtype C in T-lymphocytes and MDM may contribute to a high viral load, rapid disease progression, and spread in infected individuals $[35,36]$.

We have demonstrated that subtype C envelope V3-V5 region chimeras showed increased levels of virus entry that correlated with an increased rate of replication in primary T-lymphocytes and MDM compared with subtype B chimeras and subtype B primary isolates. Careful observation indicates that chimeras with higher rate of entry peaked earlier during infection in primary cells. Unlike the lymphotropic (X4) parental clone HIV-1 $1_{\mathrm{NL} 4-3}$, the subtype $\mathrm{C} e n v \mathrm{~V} 3-\mathrm{V} 5$ region chimeras were unable to replicate in T lymphocyte cell lines A3.01 (Fig. 2) and MT-2 (Table 3), suggesting that the chimeras had lost the T-cell line tropism of the parent clone NL4-3 because of reciprocal insertion of the V3-V5 region from subtype C patient samples. In addition, all of the subtype $\mathrm{C} e n v$ chimeras failed to produce any syncytia in MT-2 cells (Table 3 ), denoting NSI phenotypes, similar to the R5 but not NL43 isolates. Infection of U373-Magi-X4 and U373-Magi-R5 cell lines indicate that all our chimeric viruses and the control R5-tropic isolate HIV- $1_{\mathrm{BaL}}$, utilized the CCR5 coreceptor, whereas the parental HIV-1 $1_{\mathrm{NLA}-3}$ utilized the CXCR4 coreceptor (Table 3 ). These results are consistent with earlier reports that showed reciprocal insertion of the $\mathrm{V} 3$ region of an $\mathrm{R} 5$ isolate into an $\mathrm{X} 4$ molecular clone altered the tropism of an $\mathrm{X} 4$ isolate to an R5 phenotype $[10,19,23,28-30]$.

Our in-silico analysis of the V3 sequences of the subtype $\mathrm{C}$ isolates from India predicted $\mathrm{R} 5$ tropism (Table 2). This

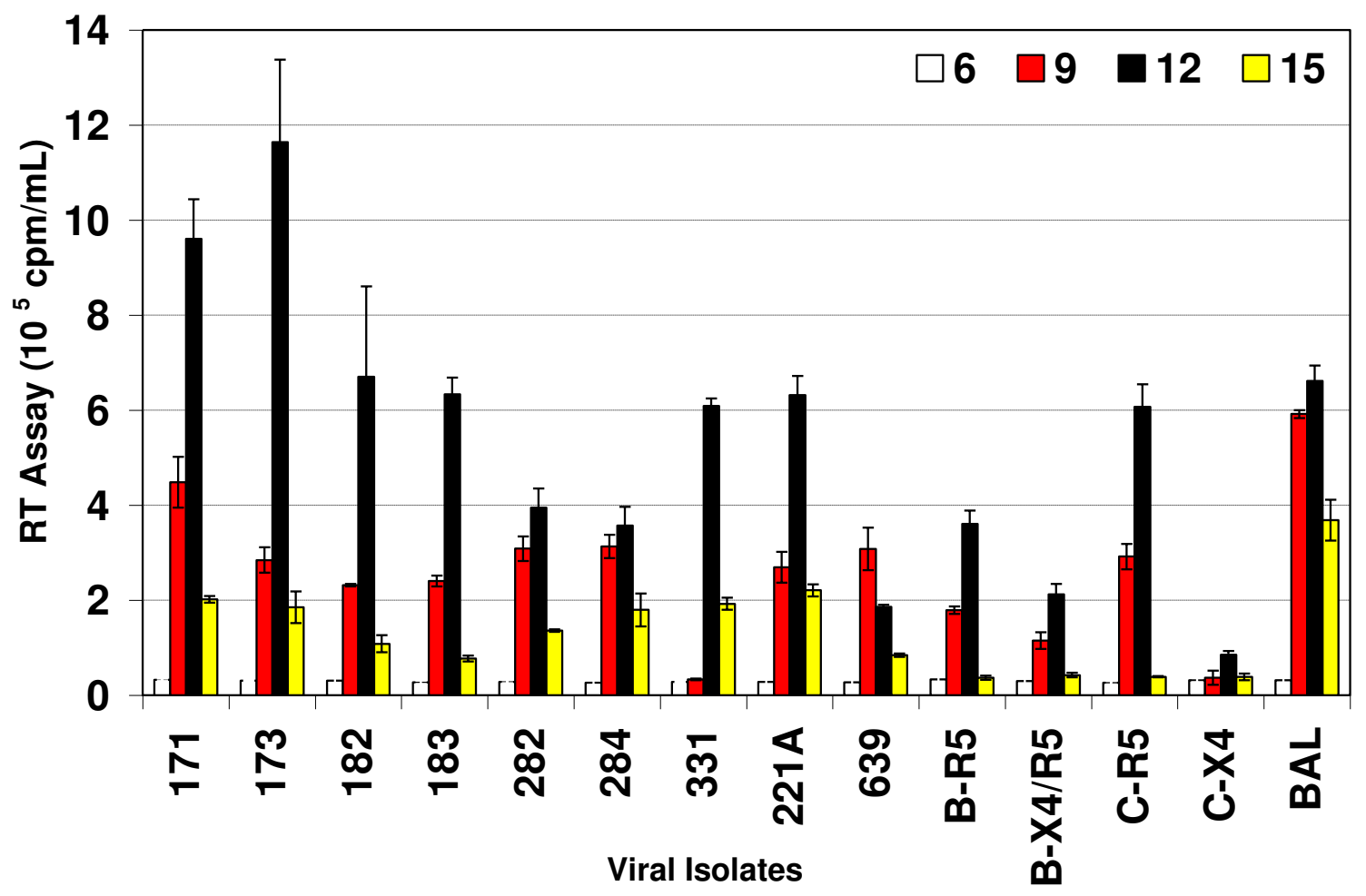

Figure 4

Replication of HIV-I subtype C env V3-V5 region chimeras in primary blood monocyte-derived macrophages (MDM). MDM $\left(0.5 \times 10^{6}\right.$ cells/well) were infected with equal amounts (RT counts) of subtype C env V3-V5 region chimeras, primary subtype $\mathrm{B}$ isolates, primary subtype $\mathrm{C}$ isolates and $\mathrm{HIV}-\mathrm{I}_{\mathrm{Ba}}$. Cells were fed every 3 days with appropriate medium and the virus production was measured in the culture supernatant by RT assay. The data are presented as cpm/ml \pm SD on triplicate experiments and are based on MDM from five different donors. 
also explains why these viruses replicated in primary blood Tlymphocytes (Fig. 3) but failed to replicate in the T4 lymphocyte cell lines, A3.01 (Fig. 2) and MT-2 because primary T-lymphocytes express CCR5, whereas and A3.01 and MT-2 do not. This data further supports the predominance of $\mathrm{R} 5$ phenotype in subtype $\mathrm{C}$ infected patients $[37,38]$ and its maintenance during symptomatic AIDS. Several of the patients that exhibited advanced stages of HIV disease (Table 1) also harbored R5 phenotype (Table $2,3)$, rarely seen in subtype B infected adult patients. In addition, the chimeras from the patients with advanced disease status (III, IV) replicated more efficiently than the less advanced disease patients (I, II) [Table 1, Figs. 3 and 4]. Furthermore, it has also been found that the percentage of CD4 T cells expressing CCR5 in Indian adults is higher than among Caucasian races [39]. It is, therefore, likely that due to the presence of this larger pool of CCR5 positive CD4 cells, the virus may not need a coreceptor switch during disease progression.

Our data showed that subtype C V3-V5 region chimeras replicated better in primary blood T-lymphocytes (Fig. 3) and MDM (Fig. 4) compared with subtype B chimeras, HIV- $1_{\mathrm{NL} 4-3}$ and subtype B primary isolates. In general, there was a correlation between higher virus entry, earlier replication peaks, and increased replication efficiencies in primary T-lymphocytes and MDM. Examination of sequence data published earlier on these patients [5] and presented in Fig. 1 and Table show several features of subtype $\mathrm{C}$ chimeras, including number of positive charges, amino acid sequence variation and number of glycosylation sites. One striking feature was that the chimeras from patient AP.17 (chimeras \# 171, 173) and AP.5 (chimeras \# 512, 514) retained the $\mathrm{N}$-linked glycosylation site that includes the first cysteine residue of V3 loop [10], whereas other chimeras had mutations in this site, contributing to the differences in replication efficiencies of these chimeras (Fig. 3). Our subtype V3-V5 region chimeras were in close resemblance with subtype C (HIV-1C) with V3 sequences similar to HIV-1 $1_{\text {BAL }}$ (R5), as shown in Fig. 1. The motif SIHIGPGRALYTTGEIIGDI that is important for $\mathrm{R} 5$ tropism as seen for HIV- $1_{\text {BAL }}$ in Fig. 1 was fairly conserved in our subtype $\mathrm{C}$ chimeras contributing to $\mathrm{R} 5$ tropism. Similarly subtype C chimeras V4-V5 region sequences show similarity to subtype $\mathrm{C}$ sequence but variability to subtype B (X4 and R5) sequences. The difference in amino acid sequences in V3 to V5 regions in subtype $\mathrm{C}$ chimeras as compared to subtype $\mathrm{B}$ sequences may be responsible for increased replication efficiencies of subtype $\mathrm{C}$ chimeras. Further studies on site directed mutagenesis of the V3-V5 regions and binding affinity of gp120 to CCR5 and/or gp120 incorporation into chimeric virions might pinpoint the major difference in replication efficiencies.
While a co-infection in vitro study with more fit subtype B and less fit subtype $\mathrm{C}$ viruses indicates more fitness of subtype B over subtype $C$ viruses [40], several in-vivo infection studies on rhesus macaques have shown that HIV-1 subtype $\mathrm{C} e n v$ chimeric viruses demonstrate greatly enhanced infectivity [41-43] and replication efficiency as compared to subtype B and E viruses $[44,45]$. Our data on higher levels of HIV-1 entry and increased replication efficiencies of subtype C chimeras compared with subtype B viruses is consistent with the latter in vivo studies [41-43]. Increased replication efficiency of subtype $C$ viruses has also been attributed to the presence of an extra NF- $\mathrm{KB}$ site in the LTR of subtype C viruses $[46,47]$. However, these viruses have shown not only to replicate efficiently but to also be transmitted and spread more efficiently than other HIV-1 subtypes [1,9]. During horizontal and vertical transmission subtype C viruses have been shown to spread more rapidly than other subtypes due to increased mucosal and vaginal shedding $[36,48,49]$. This increased transmission cannot solely be explained due to increased LTR activity as increased shedding of virus and increased transmission may be attributed to the envelope gene and others regions and functions of the virus.

While various HIV-1 subtypes prevalent in different regions of the world show variability in their replication kinetics and disease progression in infected individuals [32], HIV-1 subtype $\mathrm{C}$ is rapidly spreading and has already become the predominant subtype worldwide. The data presented in this paper indicate that HIV-1 envelope V3-V5 region of subtype $\mathrm{C}$ contributes to increased rates of replication as compared to subtype B. This would also explain higher viral loads and faster disease progression in patients infected with HIV-1 subtype C [35] as well as increased shedding of virus seen in subtype $C$ infected population $[36,48]$. Our data shows the HIV-1 subtype C envelope V3V5 region may be one of the determinants of increased virus entry and replication. These results provide another candidate gene to be responsible for the rapid spread of HIV-1 subtype $\mathrm{C}$ and its ability to dominate in populations that initially had higher incidence of other subtypes.

\section{Methods \\ Construction of HIV-I Chimeras}

Sixteen previously characterized envelope V3-V5 region sequences (Fig. 1) from nine subtype $\mathrm{C}$ Indian isolates (Table 1) [5] were reciprocally substituted into pNL4-3 in $B g l$ III-BglII sites flanking the region. The $650 \mathrm{bp}$ fragment encompassing the V3-V5 region corresponds to amino acids $240-439$ of gp120 of the HIV-I ${ }_{\text {NL4-3 }}$ sequence with the V3-loop positioned between amino acids 267 and 300 . PCR primers were designed to amplify the V3-V5 region and to replace a similar region in pNL4-3 by engineering a BglII site at the 3' end at position 7611 corresponding to all isolates. PCR amplification was carried out using Pfu 
polymerase. The $~ 600 \mathrm{bp}$ PCR product was digested with BglII and cloned into pGEM (NL4-3) using the BglII sites [50]. The BglII-BglII fragment was reciprocally exchanged into the pGEM plasmid containing the EcoRI-BamHI fragment as there were no EcoRI or BamHI sites in this a region in any Indian isolate except AP. 5 which contained an EcoRI site in the sequence. The recombinant clones were checked by digestion with BglII and the orientation was confirmed by DNA sequencing using primer (5'TCAACTGCTGTTAAATGGC3'). Finally, the modified EcoRI-BamHI fragment containing the sporadic subtype C Indian isolate V3 to V5 region was reciprocally substituted into pNL4-3. Two clones were obtained from each patient sample and these are numbered with numerals of patient identification number followed by clone number. All the clones were again checked by digestion with EcoRI/SalI and BamHI and confirmed by sequencing.

\section{Cell lines and primary cells}

HeLa cells, U373-MAGI-CXCR4 and U373-MAGI-CCR5 cell lines were cultured in DMEM with 10\% fetal bovine serum (FBS) and penicillin-streptomycin (Invitrogen). The MAGI cell media was also supplemented with $0.2 \mathrm{mg} /$ $\mathrm{ml}$ of G418, $0.1 \mathrm{mg} / \mathrm{ml}$ of hygromycin B and $1 \mu \mathrm{g} / \mathrm{ml}$ of puromycin. T-lymphocyte cell lines, A3.01 and MT-2 were cultured in RPMI 1640 supplemented with 10\% FBS and penicillin-streptomycin. Peripheral blood mononuclear cells (PBMC) were obtained by single step density gradient centrifugation with Ficoll-Hypaque (Amersham) from whole blood of normal donors. The blood collections were made after informed consent, and were approved by the Human Subject Ethical committees of International Center for Genetic Engineering and Biotechnology (ICGEB) and the Human Subjects Committee of the University of Arizona (Tucson, AZ) and were based on Indian Council of Medical Research (ICMR) and National Institutes of Health (NIH) guidelines, respectively. PBMC were collected, washed twice with cold PBS and centrifuged at $1000 \mathrm{rpm}$ for $10 \mathrm{~min}$ to avoid collecting platelets. Primary monocyte/macrophages and peripheral blood lymphocytes (PBL) were separated from PBMC using magnetic bead isolation protocols. Monocytes were isolated by CD14 magnetic bead isolation (Miltenyi biotech) according to the manufacturer's protocols. The cells bound to the CD14 bead were used as primary monocytes. The primary monocytes eluted from the CD14 isolation columns were counted and plated in 48 well plates at $1 \times 10^{6}$ cells/well in RPMI 1640 with $15 \%$ human $\mathrm{AB}$ serum (Gemini biotech) and MCSF (Sigma) for 7 days and were allowed to differentiate into macrophages in this media. The cells were fed every two days during differentiation. The cells collected as unbound flow through from the CD14 bead isolation protocol were used as PBL. PBL were cultured in RPMI 1640 with 10\% FBS and penicillinstreptomycin. PBL were stimulated with $5 \mu \mathrm{g} / \mathrm{ml}$ of PHA for $24-48 \mathrm{~h}$. The stimulated cells were washed with PBS and resuspended in RPMI 1640 with 10\% FBS and $20 \mathrm{U} /$ $\mathrm{ml}$ of recombinant human IL-2 (Invitrogen).

\section{DNA Transfections}

Subtype C chimeric proviral DNAs were transfected in HeLa cells by electroporation as described before [34] or by Lipofectamine 2000 (Invitrogen) [51]. For the Lipofectamine method, HeLa cells were grown in DMEM with $10 \%$ FBS and penicillin-streptomycin to about $80 \%$ confluency. The cells were then split and counted and plated in a 6-well plate at $10^{5}$ cells/well in DMEM with $10 \%$ FBS without antibiotics. The cells were transfected the next day with $3 \mu \mathrm{g}$ DNA in DNA-lipofectamine complexes as per manufacturer's procedure. Chimeric viruses were harvested by collecting culture supernatant from the wells 72 hrs post-transfections. Virus production was measured by a reverse transcriptase (RT) assay [34,51].

\section{Infections}

A3.01 cells $\left(2 \times 10^{6}\right)$, MT-2 $\left(2 \times 10^{6}\right)$, PBL $\left(1 \times 10^{6}\right)$ and $\operatorname{MDM}\left(0.5 \times 10^{6}\right)$ per well were cultured and infected with equal amounts of subtype $\mathrm{C} e n v$ region chimeras, subtype B V3 region chimeras (M5g, M7f, M1c) [34,50], subtype B and $\mathrm{C}$ primary isolates, and virus production was measured every 3 days. We used two subtype C (3041-R5 and 5441-X4) and two subtype B (2099-R5 and 2101-X4/R5) primary isolates that were obtained from AIDS Research and Reference Reagent Program as controls. Briefly, viruses were adsorbed in A3.01 cells, MT-2 and PBL for 90 min in serum free media at $37^{\circ} \mathrm{C}$ and $5 \% \mathrm{CO}_{2}$. After incubation, $500 \mu \mathrm{l}$ of appropriate media containing serum and antibiotics were added. MDM were infected in media containing serum and polybrene $(8 \mu \mathrm{g} / \mathrm{ml})$ incubated at $37^{\circ} \mathrm{C}$ and $5 \% \mathrm{CO}_{2}$ for 16 hrs. After incubation, the macrophages were washed in PBS to remove polybrene and resuspended in macrophage culture media.

\section{Coreceptor utilization}

U373-MAGI-CXCR4 and U373-MAGI-CCR5 cell lines were plated at $\sim 6 \times 10^{4}$ cells/well in 24 well plate in complete DMEM with G418-hygromycin-puromycin. Both cells lines were infected with 5,000 and 10,000 cpm (RT assay counts) of chimeric subtype $\mathrm{C}$ virus and primary isolate controls diluted in a total volume of $300 \mu \mathrm{l}$ of complete DMEM (without antibiotics) with DEAE-dextran (final concentration $20 \mu \mathrm{g} / \mathrm{ml}$ ). Two hours postadsorbtion, $1.5 \mathrm{ml}$ of fresh MAGI media was added. To assess the rate of entry, $40 \mathrm{~h}$ post-infection, the medium was removed and cells were fixed in 1\% formaldehyde and $0.2 \%$ glutaraldehyde for $5 \mathrm{~min}$. Then, the cells were washed with PBS and stained for 2 hrs in staining solution containing $0.2 \mathrm{M}$ potassium ferricyanide, $0.2 \mathrm{M}$ potassium ferrocyanide, $2 \mathrm{M} \mathrm{MgCl}$ and $40 \mu \mathrm{g} / \mathrm{ml} \mathrm{X-Gal.} \mathrm{After}$ staining, the cells were washed in PBS and resuspended in 
PBS with Sodium Azide. Cells stained blue were counted immediately and counts were estimated as number of blue cells per well of infected cells.

\section{Cytopathic effects (MT-2 assay)}

The syncytium-inducing ability of the subtype $\mathrm{C}$ envelope chimeras was determined and compared to a known syncytium-inducing (SI) virus (HIV-1 $\left.1_{\mathrm{NLA}-3}\right)$ and a non-syncytiuminducing (NSI) viruses (HIV- $1_{\mathrm{BaL}}$ and $\mathrm{HIV}-1_{\text {Ada-M }}$ ) by infecting the MT-2 cell line with equal amounts of these viruses. Syncytium formation was monitored every day in the cultures up to 30 days post-infection. The viruses that formed more than four syncytia per field of view in the culture were designated as SI viruses (ACTG protocol), whereas viruses that failed to induce this number of syncytia in the culture were termed NSI viruses.

\section{Competing interests}

The author(s) declare that they have no competing interests.

\section{Authors' contributions}

VS and SRD contributed equally to this work. SRD carried out the PCR, cloning, and sequencing. VS performed all biological experiments, including T-cells lines and primary cells infection experiments. RR contributed in transfections and infection experiments. SS and SG contributed to the collection of patients' samples and clinical data. VS, SRD, RR, NA and SJ participated in the experimental design, data interpretation and writing of the manuscript. All the authors read and approved the final manuscript.

\section{Acknowledgements}

This work was supported by an international collaborative grant to NA and SJ by Fogarty International Center, National Institutes of Health (TW 01345) and grants to NA by National Institute of Allergy and Infectious Diseases (AI 40378) and Arizona Biomedical Research Commission (ABRC 7002). Work in the $S J$ laboratory is also supported by internal funds from ICGEB, which in turn is supported by core funding provided by the Department of Biotechnology, Government of India. SRD was supported by a Senior Research Fellowship from Council of Scientific and Industrial Research, India. We thank AIDS Reference and Reagent Program for providing HIV-I isolates and cell lines and Roshni Mehta and Brian Wellensiek of Ahmad Lab for critically reviewing this manuscript.

\section{References}

I. Soares EA, Martinez AM, Souza TM, Santos AF, Da Hora V, Silveira J, Bastos FI, Tanuri A, Soares MA: HIV-I subtype $C$ dissemination in southern Brazil. Aids 2005, 19(Suppl 4):S8I-86.

2. Esparza J, Bhamarapravati N: Accelerating the development and future availability of HIV-I vaccines: why, when, where, and how? Lancet 2000, 355:206I-2066.

3. Mandal D, Jana S, Bhattacharya SK, Chakrabarti S: HIV type I subtypes circulating in eastern and northeastern regions of India. AIDS Res Hum Retroviruses 2002, 18:1219-1227.

4. Shankarappa R, Chatterjee R, Learn GH, Neogi D, Ding M, Roy P, Ghosh A, Kingsley L, Harrison L, Mullins Jl, et al:: Human immunodeficiency virus type $I$ env sequences from Calcutta in eastern India: identification of features that distinguish subtype $C$ sequences in India from other subtype $\mathbf{C}$ sequences. J Virol 200I, 75: 10479-10487.
5. Jameel S, Zafrullah M, Ahmad M, Kapoor GS, Sehgal S: A genetic analysis of HIV-I from Punjab, India reveals the presence of multiple variants. Aids 1995, 9:685-690.

6. Ahmad KM, Mujtaba S, Das R, Zafrullah M, Sehgal S, Jameel S: nef sequences of primary HIV type I isolates from northern India. AIDS Res Hum Retroviruses 1998, I4:149|-I493.

7. Siddappa NB, Dash PK, Mahadevan A, Jayasuryan N, Hu F, Dice B, Keefe R, Satish KS, Satish B, Sreekanthan K, et al.: Identification of subtype $C$ human immunodeficiency virus type $I$ by subtypespecific PCR and its use in the characterization of viruses circulating in the southern parts of India. J Clin Microbiol 2004, 42:2742-275।.

8. Siddappa NB, Dash PK, Mahadevan A, Desai A, Jayasuryan N, Ravi V, Satishchandra P, Shankar SK, Ranga U: Identification of unique B/ $C$ recombinant strains of HIV-I in the southern state of Karnataka, India. Aids 2005, 19:1426-1429.

9. McCormack GP, Glynn JR, Crampin AC, Sibande F, Mulawa D, Bliss L, Broadbent P, Abarca K, Ponnighaus JM, Fine PE, et al:: Early evolution of the human immunodeficiency virus type I subtype C epidemic in rural Malawi. J Virol 2002, 76:12890-12899.

10. Shioda T, Levy JA, Cheng-Mayer C: Macrophage and T cell-line tropisms of HIV-I are determined by specific regions of the envelope gp I 20 gene. Nature 199|, 349:167-169.

II. Feng Y, Broder CC, Kennedy PE, Berger EA: HIV-I entry cofactor: functional cDNA cloning of a seven-transmembrane, $G$ protein-coupled receptor. Science 1996, 272:872-877.

12. Choe H, Farzan M, Sun Y, Sullivan N, Rollins B, Ponath PD, Wu L, Mackay CR, LaRosa G, Newman W, et al.: The beta-chemokine receptors CCR3 and CCR5 facilitate infection by primary HIV-I isolates. Cell 1996, 85: I I35-I I48.

13. Palker TJ, Clark ME, Langlois AJ, Matthews TJ, Weinhold KJ, Randall RR, Bolognesi DP, Haynes BF: Type-specific neutralization of the human immunodeficiency virus with antibodies to envencoded synthetic peptides. Proc Natl Acad Sci USA 1988, 85:1932-1936.

14. Berger EA, Doms RW, Fenyo EM, Korber BT, Littman DR, Moore JP, Sattentau QJ, Schuitemaker H, Sodroski J, Weiss RA: A new classification for HIV-I. Nature 1998, 39 I:240.

15. Alkhatib G, Combadiere C, Broder CC, Feng Y, Kennedy PE, Murphy PM, Berger EA: CC CKR5: a RANTES, MIP-I alpha, MIP-Ibeta receptor as a fusion cofactor for macrophage-tropic HIV-I. Science 1996, 272:1955-1958.

16. Starcich BR, Hahn BH, Shaw GM, McNeely PD, Modrow S, Wolf $\mathrm{H}$, Parks ES, Parks WP, Josephs SF, Gallo RC, et al:: Identification and characterization of conserved and variable regions in the envelope gene of HTLV-III/LAV, the retrovirus of AIDS. Cell 1986, 45:637-648.

17. Ivanoff LA, Dubay JW, Morris JF, Roberts SJ, Gutshall L, Sternberg EJ, Hunter E, Matthews TJ, Petteway SR Jr: V3 loop region of the HIVI gp/20 envelope protein is essential for virus infectivity. Virology 1992, 187:423-432.

18. Ivanoff LA, Looney DJ, McDanal C, Morris JF, Wong-Staal F, Langlois AJ, Petteway SR Jr, Matthews TJ: Alteration of HIV-I infectivity and neutralization by a single amino acid replacement in the V3 loop domain. AIDS Res Hum Retroviruses 1991, 7:595-603.

19. Morris JF, Sternberg EJ, Gutshall L, Petteway SR Jr, Ivanoff LA: Effect of a single amino acid substitution in the V3 domain of the human immunodeficiency virus type I: generation of revertant viruses to overcome defects in infectivity in specific cell types. J Virol 1994, 68:8380-8385.

20. Rusche JR, Javaherian K, McDanal C, Petro J, Lynn DL, Grimaila R, Langlois A, Gallo RC, Arthur LO, Fischinger PJ, et al.: Antibodies that inhibit fusion of human immunodeficiency virusinfected cells bind a 24-amino acid sequence of the viral envelope, gp I 20. Proc Natl Acad Sci USA 1988, 85:3 I 98-3202.

21. Javaherian K, Langlois AJ, McDanal C, Ross KL, Eckler LI, Jellis CL, Profy AT, Rusche JR, Bolognesi DP, Putney SD, et al.: Principal neutralizing domain of the human immunodeficiency virus type I envelope protein. Proc Natl Acad Sci USA 1989, 86:6768-6772.

22. Lasky LA, Groopman JE, Fennie CW, Benz PM, Capon DJ, Dowbenko DJ, Nakamura GR, Nunes WM, Renz ME, Berman PW: Neutralization of the AIDS retrovirus by antibodies to a recombinant envelope glycoprotein. Science 1986, 233:209-212.

23. Westervelt P, Trowbridge DB, Epstein LG, Blumberg BM, Li Y, Hahn $\mathrm{BH}$, Shaw GM, Price RW, Ratner L: Macrophage tropism determinants of human immunodeficiency virus type I in vivo. J Virol 1992, 66:2577-2582. 
24. Sullivan N, Thali M, Furman C, Ho DD, Sodroski J: Effect of amino acid changes in the $V I / V 2$ region of the human immunodeficiency virus type I gp 120 glycoprotein on subunit association, syncytium formation, and recognition by a neutralizing antibody. J Virol 1993, 67:3674-3679.

25. Toohey K, Wehrly K, Nishio J, Perryman S, Chesebro B: Human immunodeficiency virus envelope $V I$ and $V 2$ regions influence replication efficiency in macrophages by affecting virus spread. Virology 1995, 213:70-79.

26. Lee CN, Robinson J, Mazzara G, Cheng YL, Essex M, Lee TH: Contribution of hypervariable domains to the conformation of a broadly neutralizing glycoprotein I 20 epitope. AIDS Res Hum Retroviruses 1995, I I:777-78।.

27. Li B, Decker JM, Johnson RW, Bibollet-Ruche F, Wei X, Mulenga J, Allen S, Hunter E, Hahn BH, Shaw GM, et al.: Evidence for potent autologous neutralizing antibody titers and compact envelopes in early infection with subtype $\mathbf{C}$ human immunodeficiency virus type I. J Virol 2006, 80:52II-52I8.

28. Hwang SS, Boyle TJ, Lyerly HK, Cullen BR: Identification of the envelope V3 loop as the primary determinant of cell tropism in HIV-I. Science I99I, 253:7|-74.

29. Chesebro B, Wehrly K, Nishio J, Perryman S: Mapping of independent $V 3$ envelope determinants of human immunodeficiency virus type I macrophage tropism and syncytium formation in lymphocytes. J Virol 1996, 70:9055-9059.

30. Korber BT, Maclnnes K, Smith RF, Myers G: Mutational trends in V3 loop protein sequences observed in different genetic lineages of human immunodeficiency virus type I. J Virol 1994, 68:6730-6744.

31. Jensen MA, Li FS, van 't Wout AB, Nickle DC, Shriner D, He HX, McLaughlin S, Shankarappa R, Margolick JB, Mullins JI: Improved coreceptor usage prediction and genotypic monitoring of R5-to-X 4 transition by motif analysis of human immunodeficiency virus type I env V3 loop sequences. J Virol 2003 77:13376-13388.

32. Peeters M, Sharp PM: Genetic diversity of HIV-I: the moving target. Aids 2000, I 4(Suppl 3):SI29-I40.

33. Zhang H, Orti G, Du Q, He J, Kankasa C, Bhat G, Wood C: Phylogenetic and phenotypic analysis of HIV type I env gp I20 in cases of subtype $\mathbf{C}$ mother-to-child transmission. AIDS Res Hum Retroviruses 2002, I 8:|4|5-|423.

34. Matala E, Hahn T, Yedavalli VR, Ahmad N: Biological characterization of HIV type I envelope V3 regions from mothers and infants associated with perinatal transmission. AIDS Res Hum Retroviruses 2001, I 7:1725-1735.

35. Mehendale SM, Bollinger RC, Kulkarni SS, Stallings RY, Brookmeye RS, Kulkarni SV, Divekar AD, Gangakhedkar RR, Joshi SN, Risbud AR, et al.: Rapid disease progression in human immunodeficiency virus type I-infected seroconverters in India. AIDS Res Hum Retroviruses 2002, I 8: I 175-I I79.

36. Overbaugh J, Kreiss J, Poss M, Lewis P, Mostad S, John G, Nduati R, Mbori-Ngacha D, Martin H Jr, Richardson B, et al.: Studies of human immunodeficiency virus type I mucosal viral shedding and transmission in Kenya. J Infect Dis 1999, I79(Suppl 3):S40I-404

37. Abebe A, Demissie D, Goudsmit J, Brouwer M, Kuiken CL, Pollakis G, Schuitemaker H, Fontanet AL, Rinke de Wit TF: HIV-I subtype $C$ syncytium- and non-syncytium-inducing phenotypes and coreceptor usage among Ethiopian patients with AIDS. Aids 1999, |3:|305-|3||.

38. Peeters M, Vincent R, Perret JL, Lasky M, Patrel D, Liegeois F, Courgnaud V, Seng R, Matton T, Molinier S, et al.: Evidence for differences in MT2 cell tropism according to genetic subtypes of HIV-I: syncytium-inducing variants seem rare among subtype C HIV-I viruses. J Acquir Immune Defic Syndr Hum Retrovirol 1999, 20:115-121.

39. Ramalingam S, Kannangai R, Vijayakumar TS, Subramanian S, Abraham OC, Rupali P, Jesudason MV, Sridharan G: Increased number of CCR5+ CD4 T cells among south Indian adults probably associated with the low frequency of X4 phenotype of HIV-I in India. Indian J Med Res 2002, I I 6:90-95.

40. Marozsan AJ, Moore DM, Lobritz MA, Fraundorf E, Abraha A, Reeves JD, Arts EJ: Differences in the fitness of two diverse wild-type human immunodeficiency virus type $I$ isolates are related to the efficiency of cell binding and entry. J Virol 2005, 79:7| $2|-7| 34$
4I. Chen Z, Huang Y, Zhao X, Skulsky E, Lin D, Ip J, Gettie A, Ho DD: Enhanced infectivity of an R5-tropic simian/human immunodeficiency virus carrying human immunodeficiency virus type I subtype $\mathbf{C}$ envelope after serial passages in pig-tailed macaques (Macaca nemestrina). J Virol 2000, 74:650I-65 I0.

42. Chen Z, Zhao X, Huang Y, Gettie A, Ba L, Blanchard J, Ho DD: CD4+ lymphocytopenia in acute infection of Asian macaques by a vaginally transmissible subtype-C, CCR5-tropic Simian/ Human Immunodeficiency Virus (SHIV). J Acquir Immune Defic Syndr 2002, 30: I33-|45.

43. Ndung'u T, Lu Y, Renjifo B, Touzjian N, Kushner N, Pena-Cruz V, Novitsky VA, Lee TH, Essex M: Infectious simian/human immunodeficiency virus with human immunodeficiency virus type I subtype $\mathbf{C}$ from an African isolate: rhesus macaque model. J Virol 2001, 75: I|4I7-I|425.

44. Bogers WM, Dubbes $R$, ten Haaft $P$, Niphuis $H$, Cheng-Mayer $C$, Stahl-Hennig C, Hunsmann G, Kuwata T, Hayami M, Jones S, et al.: Comparison of in vitro and in vivo infectivity of different clade B HIV-I envelope chimeric simian/human immunodeficiency viruses in Macaca mulatta. Virology 1997, 236: II0-II7.

45. Himathongkham S, Halpin NS, Li J, Stout MW, Miller CJ, Luciw PA: Simian-human immunodeficiency virus containing a human immunodeficiency virus type I subtype-E envelope gene: persistent infection, CD4(+) T-cell depletion, and mucosal membrane transmission in macaques. J Virol 2000, 74:785I-7860.

46. Novitsky V, Smith UR, Gilbert P, McLane MF, Chigwedere P, Williamson C, Ndung'u T, Klein I, Chang SY, Peter T, et al.: Human immunodeficiency virus type I subtype $\mathbf{C}$ molecular phylogeny: consensus sequence for an AIDS vaccine design? J Virol 2002, 76:5435-545I.

47. Munkanta M, Handema R, Kasai H, Gondwe C, Deng X, Yamashita A, Asagi T, Yamamoto N, Ito $M$, Kasolo $F$, et al:: Predominance of three NF-kappaB binding sites in the long terminal repeat region of HIV Type I subtype $\mathbf{C}$ isolates from Zambia. AIDS Res Hum Retroviruses 2005, 21:901-906.

48. John-Stewart GC, Nduati RW, Rousseau CM, Mbori-Ngacha DA, Richardson BA, Rainwater S, Panteleeff DD, Overbaugh J: Subtype $C$ Is associated with increased vaginal shedding of HIV-I. J Infect Dis 2005, 192:492-496.

49. Renjufi B, Gilbert P, Chaplin B, Msamanga G, Mwakagile D, Fawzi W, Essex M: Preferential in-utero transmission of HIV-I subtype C as compared to HIV-I subtype A or D. Aids 2004, I 8:1629-1636.

50. Ahmad N, Baroudy BM, Baker RC, Chappey C: Genetic analysis of human immunodeficiency virus type I envelope V3 region isolates from mothers and infants after perinatal transmission. J Virol 1995, 69:1001-1012.

5I. Sundaravaradan V, Saxena SK, Ramakrishnan R, Yedavalli VRK, Harris DT, Ahmad N: Differential HIV-I replication in neonatal and adult blood mononuclear cells is influenced at the level of HIV-I gene expression. Proc Natl Acad Sci USA 2006 in press.

Publish with Bio Med Central and every scientist can read your work free of charge

"BioMed Central will be the most significant development for disseminating the results of biomedical research in our lifetime. "

Sir Paul Nurse, Cancer Research UK

Your research papers will be:

- available free of charge to the entire biomedical community

- peer reviewed and published immediately upon acceptance

- cited in PubMed and archived on PubMed Central

- yours - you keep the copyright 